\title{
Relationship of Self Control, Critical Thinking, Motivation with Volleyball Games
}

\author{
Budi Gunawan* \\ Universitas Pendidikan Indonesia \\ Bandung, Indonesia \\ *Gunawan87.bg@gmail.com
}

\begin{abstract}
Physical education should be a tool to achieve educational goals. However, in the learning process, there is often no teaching process. Teaching is very ineffective, sometimes the learning is meaningless and does not convey educational messages. This is certainly not independent of the role of the teacher as the holder of the control of the learning process. Teacher-centered learning seems to limit students to explore students' abilities in the learning process. The teacher's determination in determining the learning strategies in the classroom is very helpful in achieving successful learning. To achieve successful learning, teachers should be able to accommodate aspects of the human person, optimize the whole work of the brain and be able to generate high motivation from students. The teacher's creativity is at stake to be able to design learning tools that can accommodate these aspects in all competencies. This study uses a quantitative approach method. The purpose of this study will see from the relationship of selfcontrol with physical activity in volleyball games, the relationship of critical thinking with physical activity, the relationship of motivation with physical activity so that there is an increase in volleyball games. With a sample of 22 people Hypothesis analysis was carried out using Path Analysis method because it is more in line with the case presented in this study. The instrument used is a physical activity test by giving a questionnaire. The results show that 1). There is a significant effect of the relationship between self-control and physical activity in volleyball 2 ). There is a significant effect of the relationship of critical thinking with physical activity in volleyball 3 ). there is a significant effect of achievement motivation with physical activity in volleyball games. Furthermore, the authors suggest that physical education teachers in the selection of material in the learning process is adjusted to the principle, because it will provide very good benefits, especially in improving learning outcomes such as aspects of skills development, cognitive development, social development and physical development.
\end{abstract}

Keywords-self control; critical thinking; motivation; volleyball; physical education

\section{INTRODUCTION}

Physical education is essentially an educational process that utilizes physical activity to produce holistic changes in individual qualities, both physically, mentally, and emotionally. Mahendra explain that penjas learning can contribute 'Improve physical fitness and health [1]. In fact, the main emphasis has been on competitive sports, starting in third grade and continuing throughout high school [2].
Physical Education can provide a context that allows students to learn about emotional expression and control in stressful situations [3]. It can have an impact on many, or even all, goals from a psychological perspective. A new focus on these results may also have a detrimental effect on the development of the use of Dynamic Assessment with a focus on learning and products [4]. Complex systems, on the other hand, consist of self-regulating parts and interact with each other in their own structure and also with the external environment in which they operate [5].

Description of self-control as disclosed; Calhoun and Acocella define self-control as a regulation of physical, psychological, and behavioral processes in a person; in other words, a series of processes that shape themselves [6]

The literature on critical thinking is rooted in two main academic disciplines: philosophy and psychology [7]. According to Mc Clelland the notion of achievement motivation is defined as an effort to achieve success or success in a competition with a measure of excellence that can be in the form of other people's achievements or achievements [8].

\section{RESEARCH METHODS}

This study uses descriptive analysis described by Nur Indrianto [9]. This method is also used to test hypotheses or answer research questions. Similarly, Descriptive methods can be used for correlation research [10].

\section{A. Validity Test}

Related to testing the validity of the instrument, validity is a measure that shows the level of reliability or achievement of a measuring instrument [11]. Measuring instruments that are less valid means having low validity. To test the validity of the measuring instrument, the product moment correlation formula used by Sumarsono [12] is:

$$
r_{x y} \frac{N \sum X Y-\left(\sum X\right)\left(\sum Y\right)}{\sqrt{\left\{N \sum X^{2}-\left(\sum X\right)^{2}\right\}\left\{N \sum Y^{2}-\left(\sum Y\right)^{2}\right\}}}
$$

Where:

$\mathrm{r}$ count $=$ correlation coefficient

$\boldsymbol{\Sigma} \mathrm{Xi}=$ number of item scores

$\mathrm{IY} \mathrm{i}=$ total score 


\section{$\mathrm{n}=$ number of respondents [13]}

By using a significant level $=0.05$ the correlation coefficient obtained from the calculation results is compared with the value of the correlation table of the value of $r$ with the degree of freedom $(n-2)$, where $n$ states the number of respondents. If r $\neg$ count> $\mathrm{r} 0.05$ is said to be valid, conversely if $\mathrm{r} \square \mathrm{r} 5 \mathrm{r} 0.05$ is invalid.

\section{B. Reliability Testing}

Reliability test is a test used in research to find out whether the data collection tool used shows the level of accuracy, level of accuracy, stability, and consistency in expressing symptoms from a group of individuals even though they are carried out at different times. To calculate the reliability test, this study uses alpha formula from Cronbach as follows:

$$
r_{11}=\left[\frac{k}{k-1}\right]\left[1-\frac{\Sigma \sigma_{n}^{2}}{\sigma_{t}^{2}}\right]
$$

Where;

$$
\begin{aligned}
& \mathrm{r}_{11}=\text { instrument reliability } \\
& \mathrm{k}=\text { many items of statements or number of questions } \\
& \Sigma \sigma_{n}{ }^{2}=\text { Amount of item variance } \\
& \sigma_{t}^{2}=\text { total variance [14] }
\end{aligned}
$$

Measurement of reliability is done by one shot or measurement once with the SPSS Cronbach Alpha $(\alpha)$ statistical test. A construct or variable is said to be reliable if it gives a Cronbach Alpha value> 0.70 [15].

\section{RESEARCH RESULTS AND DISCUSSION}

\section{A. Testing of Research Instruments}

1) Validity test: Validity tests are used to measure the validity or validity of a questionnaire. All questionnaire items that have $r$ count $>r$ table at $n=22$ which is 0.423 are declared valid. While items that have a correlation coefficient value below 0.423 are considered invalid and invalid items can be removed. In the table above it can be seen that the index value of the validity of each item statement on the variables of Self Control, Critical Thinking, and Motivation in the physical activity of Volleyball games is greater than 0.423 so it can be concluded that all items are valid and feasible to be used as measuring instruments.

2) Reliability test: Reliability test is a tool to measure a questionnaire which is an indicator of a variable or construct. Measurement of reliability is done by one shot or measurement once with the SPSS Cronbach Alpha $(\alpha)$ statistical test. A construct or variable is said to be reliable if it gives the value of Cronbach Alpha> 0.70 [16]. The reliability value of the statement items on the questionnaire on the Organizational Structure and Volleyball Achievement variables of more than 0.70 . These results indicate that the questionnaire items are reliable for measuring variable variables Self Control, Critical Thinking, and Motivation in physical activity of Volleyball games.

\section{B. Descriptive Analysis}

- To find out how the conditions and the degree of suitability of each of these variables, the researcher makes the categorization in the interval lines as follows:

- The total number of respondents is 22 people and for the largest measurement scale value is 5 while the smallest measurement scale value is 1 .

- The ideal average score is $5 \times 22=110$ and the smallest average score is $1 \mathrm{X} 22=22$. The smallest percentage value is $(22: 110) \mathrm{X} 100 \%=20 \%$.

- Obtained a value range of $100 \%-20 \%=80 \%$ if divided into 5 measurement scales will get a percentage interval of $16 \%$, then the score interpretation category can be seen in table 1 below:

TABLE I. TABLE INTERPRETATION CATEGORY SCORES

\begin{tabular}{|c|c|}
\hline The Calculation Results & Category \\
\hline $20 \% \mathrm{~s} / \mathrm{d} 36 \%$ & Poor \\
\hline $37 \% \mathrm{~s} / \mathrm{d} 52 \%$ & Not Good \\
\hline $53 \% \mathrm{~s} / \mathrm{d} 68 \%$ & Pretty Good \\
\hline $69 \% \mathrm{~s} / \mathrm{d} 84 \%$ & Good \\
\hline $85 \% \mathrm{~s} / \mathrm{d} 100 \%$ & Very Good \\
\hline
\end{tabular}

Results of Processing Researchers, 2018

1) Effect of self control on physical activity of volleyball games: The statement is in line with the results of testing the hypothesis that the Self Control has a significant effect on the physical activity of Volleyball games, this is indicated by tcount $>\mathrm{t}$ table, which is 3.082 $>2.101$ and known as sig. $(0.006)<0.05$ so that $\mathrm{H} 0$ is rejected. The results of this study are in line with the research of Intani which shows that there is a significant positive relationship between self-control and physical activity [17].

2) The effect of critical thinking on the physical activity of volleyball games: In line with the statement above, the testing of this hypothesis shows that Critical Thinking has a significant effect on the physical activity of Volleyball games, this is indicated by the tcount $>$ ttable, which is $2.470>2.101$, besides that it is known sig. $(0.024)<0.05$ so that $\mathrm{H} 0$ is rejected. The results of this study support the results of research conducted by Sihaloho which states that critical thinking skills have a strong and significant correlation to physical activity [18].

3) The effect of motivation on the physical activity of volleyball games: In line with the testing of this third hypothesis, it was found that Motivation had a significant effect on the physical activity of Volleyball games, it was shown by the value of tcount $>t$ table which is $2.255<2.101$, besides that it is known sig. $(0.037)<0.05$ so that $\mathrm{H} 0$ is rejected. With a positive directional correlation coefficient that shows that the better the Motivation will have an impact on the physical activity of Volleyball games which are getting 
higher and vice versa the worse the Motivation will have an impact on the Lower Volleyball Branch Learning Achievement. This research is in line with the results of Ulum which shows that there is a positive and significant relationship between motivation [19].

4) Effect of self control, critical thinking and motivation on volleyball physical activity: Based on simultaneous hypothesis testing, it was found that Self Control, Critical Thinking and Motivation had a significant simultaneous effect on the physical activity of Volleyball games, this is indicated by the value of F Count> Ftable (48.318> 3.16) and the sig value. $(0,000)<0.05$ so that $\mathrm{H} 0$ is rejected. The coefficient of determination is 0.89 , meaning the influence of Self Control, Critical Thinking and Motivation simultaneously with Volleyball physical activity by $89 \%$, while the remaining $11 \%$ is the influence of other variables that are not observed.

a) Self control in students at lembang 7th elementary school: The variable Self Control with the number of statement items as many as 3 items and the number of respondents as many as 22 students obtained a total score of 240 with a percentage of $72.73 \%$, based on the calculation of the score range in the previous explanation, the results of interpretations of respondents' responses regarding Self Control included in the good category. this shows that the ability of students' physical and psychological behavior, in other words a series of processes that shape their own students are considered good.

b) Critical thinking of students at lembang elementary school 7: Critical thinking skills are the ability to think at a complex level and use the process of analysis and evaluation.

Critical Thinking variable with the number of statement items as many as 5 items and the number of respondents as many as 22 Students obtained a total score of 447 with a percentage of $81.27 \%$, based on the calculation of the score range in the previous explanation, the results of the respondents' responses to Critical Thinking were included in the good category. this shows that SD Negeri 7 Lembang Students are considered good in their ability to think on a complex level and use the process of analysis and evaluation.

c) Motivation for students at lembang elementary school 7: Motivation for achievement is defined as an effort to achieve success or success in competition with a measure of excellence that can be in the form of other people's achievements or their own achievements [8]. Motivation variables with the number of statement items as many as 6 items and the number of respondents as many as 22 students obtained a total score of 475 with a percentage of $71.97 \%$, based on the calculation of the range of scores in the previous explanation, the results of the respondents' responses to motivation were included in the good category. shows that SD Negeri 7 Lembang students have a good drive in achieving success in competition with a measure of excellence that can be in the form of other people's achievements or their own achievements. d) Physical activity of volleyball games at SD Negeri 7 Lembang: Thus someone who has high self control can minimize the occurrence of things that are not desired by students, especially the results of low learning achievement. The statement is in line with the results of testing the hypothesis that the Self Control has a significant effect on the Learning Outcomes of Volleyball Branches, this is indicated by tcount $>\mathrm{t}$ table, which is 3.082> 2.101 and known as sig. (0.006) $<0.05$ so that $\mathrm{HO}$ is rejected. With a positive directional correlation coefficient which shows that the better the Self Control will have an impact on the Higher Volleyball Branch Learning Results and vice versa the worse the Self Control will have an impact on the Lower Volleyball Branch Learning Achievement.

Cottrell which explains that critical thinking skills are needed in learning activities because the development of critical thinking skills in learning activities will contribute positively to student learning achievement [20]. In line with the statement above, the testing of this hypothesis shows that Critical Thinking has a significant effect on the Learning Outcomes of Volleyball Branches, this is indicated by the tcount $>$ ttable which is $2.470>2.101$, besides that it is known sig. $(0.024)<0.05$ so that $\mathrm{H} 0$ is rejected. With a positive directional correlation coefficient which shows that the better Critical Thinking will have an impact on the Learning Outcomes of Volleyball Branches the higher the opposite the worse the Critical Thinking will have an impact on the Lower Volleyball Branch Learning Achievement

In line with the testing of this third hypothesis, it was found that Motivation had a significant effect on the Volleyball Branch Learning Outcomes, this was indicated by the tcount $>t$ table which was $2.255<2.101$, besides that it was known to be sig. (0.037) <0.05 so that $\mathrm{H} 0$ is rejected. With a positive directional correlation coefficient which indicates that the better the Motivation will have an impact on the Learning Outcomes of Volleyball Branches which are getting higher and vice versa the worse the Motivation will have an impact on the Volleyball Branch Learning Results which are getting lower.

Based on simultaneous hypothesis testing, it was found that Self Control, Critical Thinking and Motivation had a significant simultaneous effect on Volleyball Branch Learning Achievements, this was indicated by the value of F Count $>$ Ftable $(48.318>3.16)$ and the sig value. $(0,000)<0.05$ so that $\mathrm{HO}$ is rejected. The coefficient of determination is 0.89 , meaning that the influence of Self Control, Critical Thinking and Motivation simultaneously with Volleyball Branch Learning Achievement is $89 \%$, while the remaining $11 \%$ is the influence of other variables that are not observed.

\section{CONCLUSION}

Simultaneously it was found that Self Control, Critical Thinking and Motivation had a significant relationship to the Learning Outcomes of Volleyball Branches. The coefficient of determination is 0.89 , meaning that the influence of Self Control, Critical Thinking and Motivation simultaneously with Volleyball Branch Learning Results is $89 \%$, while the remaining $11 \%$ is the influence of other variables that are not observed. 


\section{REFERENCES}

[1] Mahendra, Principles and Philosophy of Physical Education. Teaching Materials in PLPG Training. Teacher Certification Program for Rayon X-Prov. West Java, 2008.

[2] J.G. Ross and R.R. Pate, "The National Children and Youth Fitness Study II: A summary of findings," Journal of Physical Education, Recreation and Dance, vol. 58, pp. 51-56, 1987.

[3] S.C. Ang and D. Penney, "Promoting social and emotional learning outcomes in physical education: Insights from a school-based research project in Singapore," Asia-Pacific Journal of Health, Sport and Physical Education, vol. 4, pp. 267-286, 2013.

[4] D. Buck, "Reconstructing educational psychology reports: an historic opportunity to change educational psychologists' advice?" Educational Psychology in Practice, vol. 31, pp. 221-34, 2015.

[5] M. Jess, J. Keay and N. Carse, "Primary physical education: A complex learning journey for children and teachers," Sport, Education and Society, vol. 21, pp. 1018-1035, 2016.

[6] J.F.C.J.R. Acocella and J.F. Calhoun, Psychology of Adjustment and Human Relationships. New York, 1990

[7] A. Lewis and D. Smith, "Defining higher order thinking," Theory into practice, vol. 32, pp. 131-137, 1993.

[8] D.C. McClelland, Human motivation. CUP Archive, 1987.

[9] N. Indrianto and B. Supomo, Metodologi penelitian bisnis. Yogyakarta: BPE-Yogyakarta, 2002.
[10] S. Suryabrata, Metode Pene-litian. Jakarta: PT. Raja Grafindo Persada, 2003

[11] S. Arikunto, Prosedur Penelitian Dari Teori Ke Praktek. Jakarta: Rineka Cipta, 1995.

[12] S. Sumarsono, Metode riset sumber daya manusia. Yogyakarta: Graha Ilmu, 2004.

[13] Arikunto, Research Procedures A Practice Approach. Jakarta: Rineka Cipta, 2006.

[14] S. Arikunto, Prosedur Penelitian (edisi revisi). Jakarta: Rineka Cipta, 2002.

[15] I. Ghozali, Application of multivariate analysis with SPSS program Semarang: Diponegoro University Publishing Agency, 2011.

[16] I. Ghozali, Analisis Multivariate dengan program SPSS. Semarang: Badan Penerbit Universitas Diponegoro, 2005

[17] C.P. Intani and I. Ifdil, "Hubungan kontrol diri dengan prestasi belajar siswa," Jurnal EDUCATIO: Jurnal Pendidikan Indonesia, vol. 4, pp. 65 70, 2018.

[18] F.A.S. Sihaloho, "Hubungan Kemampuan Berpikir Kritis Dan Soft Skills Dengan Prestasi Belajar Siswa Pada Mata Pelajaran Ekonomi Kelas XI SMAN 1 Labuhan Deli TP 2015/2016," Prosiding Seminar Pendidikan Ekonomi dan Bisnis, vol. 3, no. 1, 2017.

[19] A.S. Ulum, "Pengaruh Orientasi Etika terhadap Independensi dan Kualitas Audit Auditor BPK-RI," Journal of Accounting and Investment, vol. 6, pp. 74-93, 2016.

[20] S. Cottrell, Critical thinking skills: Effective analysis, argument and reflection. Macmillan International Higher Education, 2017. 